\title{
Beste $\mathrm{xx}$
}

\section{E-mail}

Volgens onze informatie bent $u$ betrokken bij [de advisering van het CBS aangaande statistieken over gezondheid en welzijn, in de [CBS expertgroep gezondheid en zorg] OR [de ontwikkeling van beleid rond langdurige zorg en/of administratie in de zorg] OR [onderzoek op het gebied van overheadkosten en administratie in de zorg].

$\mathrm{W}, \mathrm{Y}, \mathrm{Z}$ en ikzelf doen momenteel in het kader van mijn dissertatie wetenschappelijk onderzoek naar het inzichtelijk krijgen van administratieve kosten in de zorg. We bestuderen primair of het mogelijk is om de totale omvang en ontwikkeling van de administratieve kosten in de sector van de langdurige- en de Wmo-zorg in kaart te brengen.

Voor ons onderzoek hebben we data en studies verzameld over 1) de tijd besteed aan andere taken dan zorg door zorgprofessionals (micro niveau), 2) de overheadkosten van langdurige zorginstellingen (meso niveau), en 3) de beheerskosten van organisaties in de langdurige zorg betrokken bij het besturen en/of financieren (macro niveau). We zouden u willen vragen om een vragenlijst in te vullen, waarin u kunt reageren op onze beoordeling van de compleetheid en kwaliteit van de tot op heden geïdentificeerde data en studies.

Op basis van de ingevulde vragenlijsten willen we prioritaire 'blinde vlekken' in de bestaande data identificeren, en potentiële strategieën uitwerken om deze te adresseren. We nodigen $u$ graag uit om deze blinde vlekken en strategieën te bespreken in een (virtuele) expertsessie. U kunt aan het eind van de vragenlijst aangeven of $u$ hiertoe bereid bent.

U kunt de vragenlijst beginnen door op de volgende link te klikken https://www.radboudumc-surveys.nl/iqh/v206/index.php/884638?lang=nl

U dient vervolgens de volgende unieke token code in te voeren: *TOKEN*

We zouden het waarderen als u uw expertise beschikbaar wilt stellen ten behoeve van ons onderzoek. Het invullen van de vragenlijst neemt tussen de 20 en 40 minuten tijd in beslag.

Indien u vragen heeft over de opzet en het doel van het onderzoek, aarzel niet $\mathrm{X}$ te mailen

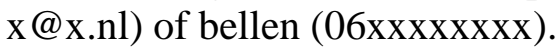

Alvast bedankt voor het in overweging nemen van ons verzoek.

Hoogachtend,

$\mathrm{X}$

$\mathrm{W}$

Y

Z 


\section{Introductie survey}

\section{Definitiekader}

In deze vragenlijst vragen we $u$ om te reageren op de compleetheid van en bevindingen uit door ons geïdentificeerde databronnen/studies voor het identificeren van administratieve kosten in de Nederlandse langdurige zorg. Ons onderzoek heeft een verkennend karakter. Daarom hanteren we een breed definitiekader van administratieve kosten. We scharen hier alle taken en functies onder binnen het systeem van de langdurige zorg, behalve directe patiëntenzorg. In wezen gaat het ons dus om alle indirecte kosten. We zijn ons ervan bewust dat hier ook taken onder vallen die overlap vertonen met directe patiëntenzorg, zoals indicatiestelling of klinische documentatie. We doen geen onderzoek naar de waarde van administratieve activiteiten en overheadkosten op zich, of de efficiëntie waarmee deze activiteiten worden uitgevoerd.

We maken in de vragenlijst onderscheid naar 3 niveaus:

\begin{tabular}{|l|l|}
\hline Micro & $\begin{array}{l}\text { De tijd die zorgprofessionals, werkzaam in de langdurige zorg, besteden aan andere } \\
\text { taken dan directe patiëntenzorg, zoals overleggen, en klinische en administratieve } \\
\text { documentatie. }\end{array}$ \\
\hline Meso & $\begin{array}{l}\text { Overheadkosten van langdurige zorginstellingen. Dit omvat functies als bestuur, } \\
\text { management, communicatie, secretariaten, beleidsadvisering, juridische bijstand, } \\
\text { financiering \& administratie, ICT en HR. }\end{array}$ \\
\hline Macro & $\begin{array}{l}\text { Beheers-/uitvoeringskosten van organisaties die (onder andere) langdurige zorg } \\
\text { besturen en/of financieren, zoals het ministerie van VWS, de WMO-afdelingen van } \\
\text { gemeenten, zorgkantoren en ZBO's in het VWS-domein. We beschouwen alle } \\
\text { kosten van deze organisaties als overhead, omdat geen van deze organisaties zelf } \\
\text { directe patiëntenzorg levert. }\end{array}$ \\
\hline
\end{tabular}

Onder 'langdurige zorg' verstaan we de onderdelen van de zorg die directe invloed hebben ondervonden van de stelselwijziging van de AWBZ naar de Wlz, Wmo2015 en delen van de Zvw. Hieronder vallen de sectoren verpleging, verzorging en thuiszorg (VVT), gehandicaptenzorg (GHZ) en de maatschappelijke opvang en beschermd wonen (RIBW). We zijn ons ervan bewust dat ook andere actoren gevolgen ondervinden door de hervormingen in 2015, zoals patiënten, PGB-houders, de jeugdzorg en aanbieders die samenwerken met professionals in de langdurige zorg, zoals huisartsen. Deze sectoren vallen echter buiten de scope van ons onderzoek.

\section{Opzet vragen}

De vragen zijn opgedeeld in drie vraaggroepen: op micro, meso en macro niveau. Indien u onvoldoende bekend bent met een van deze niveaus, dan kunt $u$ de betreffende vraaggroep overslaan. Gemeenten worden in deze vragenlijst meegenomen in vraaggroep drie (macro niveau). Het deel dat binnen deze vraaggroep over gemeenten gaat, kunt u ook overslaan indien $\mathrm{u}$ onvoldoende bekend bent met uitgaven aan langdurige zorg door gemeenten. 


\section{Vraaggroep 1 - Micro deel. Administratieve taken uitgevoerd door professionals werkzaam in de VVT, GHZ of RIBW}

Bent $\mathrm{u}$ bekend met data over dit niveau? Het gaat bijvoorbeeld om de tijd die professionals in de langdurige zorg besteden aan administratieve taken of vergaderingen over andere zaken dan patiëntenzorg.

$\mathrm{Ja} / \mathrm{nee}$

Voor het micro gedeelte hebben we diverse onderzoeken gevonden waarin met een vragenlijst aan zorgprofessionals werd gevraagd hoeveel tijd zij besteden aan administratieve taken. Onderstaande tabel geeft de hoofdbevindingen weer van enkele recente onderzoeksrapporten.

\begin{tabular}{|c|c|c|c|c|}
\hline Bron & Setting & $\begin{array}{l}\text { Brondat } \\
\text { a }\end{array}$ & $\begin{array}{l}\text { Zelf } \\
\text { gerapporteerde } \\
\text { tijd besteed aan } \\
\text { administratieve } \\
\text { taken }\end{array}$ & $\begin{array}{l}\text { 'Acceptabele' } \\
\text { tijd besteed aan } \\
\text { administratieve } \\
\text { taken }\end{array}$ \\
\hline \multirow{3}{*}{$\begin{array}{l}\text { KPMG } \\
\text { Merkbaarheidssca } \\
\text { n rapport }\end{array}$} & $\begin{array}{l}\text { Wijkverpleegkundig } \\
\text { en }(n=343)\end{array}$ & \multirow{3}{*}{2019} & $27 \%$ & $16 \%$ \\
\hline & $\begin{array}{l}\text { WMO + Jeugdzorg } \\
\text { Alkmaar }(n=76)\end{array}$ & & $41 \%$ & $21 \%$ \\
\hline & $\begin{array}{l}\text { WMO + Jeugdzorg } \\
\text { Twente }(n=16)\end{array}$ & & $43 \%$ & $26 \%$ \\
\hline \multirow{8}{*}{ Berenschot } & VVT $(n=577)$ & \multirow{2}{*}{2019} & $35 \%$ & $23 \%$ \\
\hline & GHZ $(n=1001)$ & & $33 \%$ & $22 \%$ \\
\hline & VVT $(n=375)$ & \multirow{2}{*}{2018} & $27 \%$ & $16 \%$ \\
\hline & GHZ $(n=401)$ & & $31 \%$ & $18 \%$ \\
\hline & VVT $(n=681)$ & \multirow{2}{*}{2017} & $20 \%$ & $12 \%$ \\
\hline & GHZ $(n=212)$ & & $25 \%$ & $13 \%$ \\
\hline & VVT $(n=98)$ & \multirow{2}{*}{2016} & $25 \%$ & $17 \%$ \\
\hline & GHZ $(n=975)$ & & $23 \%$ & $15 \%$ \\
\hline VvAA & $\begin{array}{l}\text { Gemiddelde van } \\
\text { huisartsen, medisch } \\
\text { specialisten, } \\
\text { fysiotherapeuten, }\end{array}$ & 2019 & $\mathrm{n} / \mathrm{a}$ & $\begin{array}{l}\text { Tijd gerelateerd } \\
\text { aan 'regels die } \\
\text { niet effectief } \\
\text { zijn en die }\end{array}$ \\
\hline
\end{tabular}




\begin{tabular}{|c|c|c|c|c|}
\hline & $\begin{array}{l}\text { tandartsen, } \\
\text { apothekers, } \\
\text { psychologen/ } \\
\text { psychotherapeuten } \\
\text { en verpleegkundigen } \\
(\mathrm{n}=11454)\end{array}$ & & & $\begin{array}{l}\text { belastend zijn } \\
\text { om na te leven': } \\
30 \%\end{array}$ \\
\hline \multirow{4}{*}{$\begin{array}{l}\text { Nivel Panel } \\
\text { Verpleging } \\
\text { \&Verzorging }\end{array}$} & \multirow{2}{*}{$\begin{array}{l}\text { Verpleegkundigen en } \\
\text { agogisch opgeleide } \\
\text { begeleiders in de } \\
\text { gehandicaptenzorg }\end{array}$} & $\begin{array}{l}2019^{1} \\
(n=151)\end{array}$ & 8,9 uur per week & $\begin{array}{l}62,8 \% \text { ervaart } \\
\text { regelmatig tot } \\
\text { altijd verhoogde } \\
\text { werkdruk door } \\
\text { registratiewerk }\end{array}$ \\
\hline & & $\begin{array}{l}2017^{2} \\
(n=215)\end{array}$ & 9,2 uur per week & $\begin{array}{l}67 \% \text { vindt } \\
\text { administratieve } \\
\text { druk (veel) te } \\
\text { hoog }\end{array}$ \\
\hline & \multirow[b]{2}{*}{$\begin{array}{l}\text { Wijkverpleegkundig } \\
\text { en en -verzorgenden }\end{array}$} & $\begin{array}{l}2019^{1} \\
(n=305)\end{array}$ & 10,0 uur per week & $\begin{array}{l}67,1 \% \text { ervaart } \\
\text { regelmatig tot } \\
\text { altijd verhoogde } \\
\text { werkdruk door } \\
\text { registratie }\end{array}$ \\
\hline & & $\begin{array}{l}2017^{2} \\
(n=438)\end{array}$ & $\begin{array}{l}13,2 \text { uur per week } \\
\text { (verpleegkundige } \\
\text { n) en } 6,6 \text { uur } \\
\text { (verzorgenden) }\end{array}$ & $\begin{array}{l}61 \% \text { van } \\
\text { verpleegkundige } \\
\text { n en } 55 \% \text { van } \\
\text { verzorgenden } \\
\text { vindt } \\
\text { administratieve } \\
\text { druk (veel) te } \\
\text { hoog }\end{array}$ \\
\hline
\end{tabular}

\footnotetext{
${ }^{1}$ Onderdeel van grotere survey: https://nivel.nl/sites/default/files/bestanden/1003571.pdf

${ }^{2}$ Als aparte survey gericht op administratie:

https://nivel.nl/sites/default/files/bestanden/factsheet administratie druk.pdf
} 


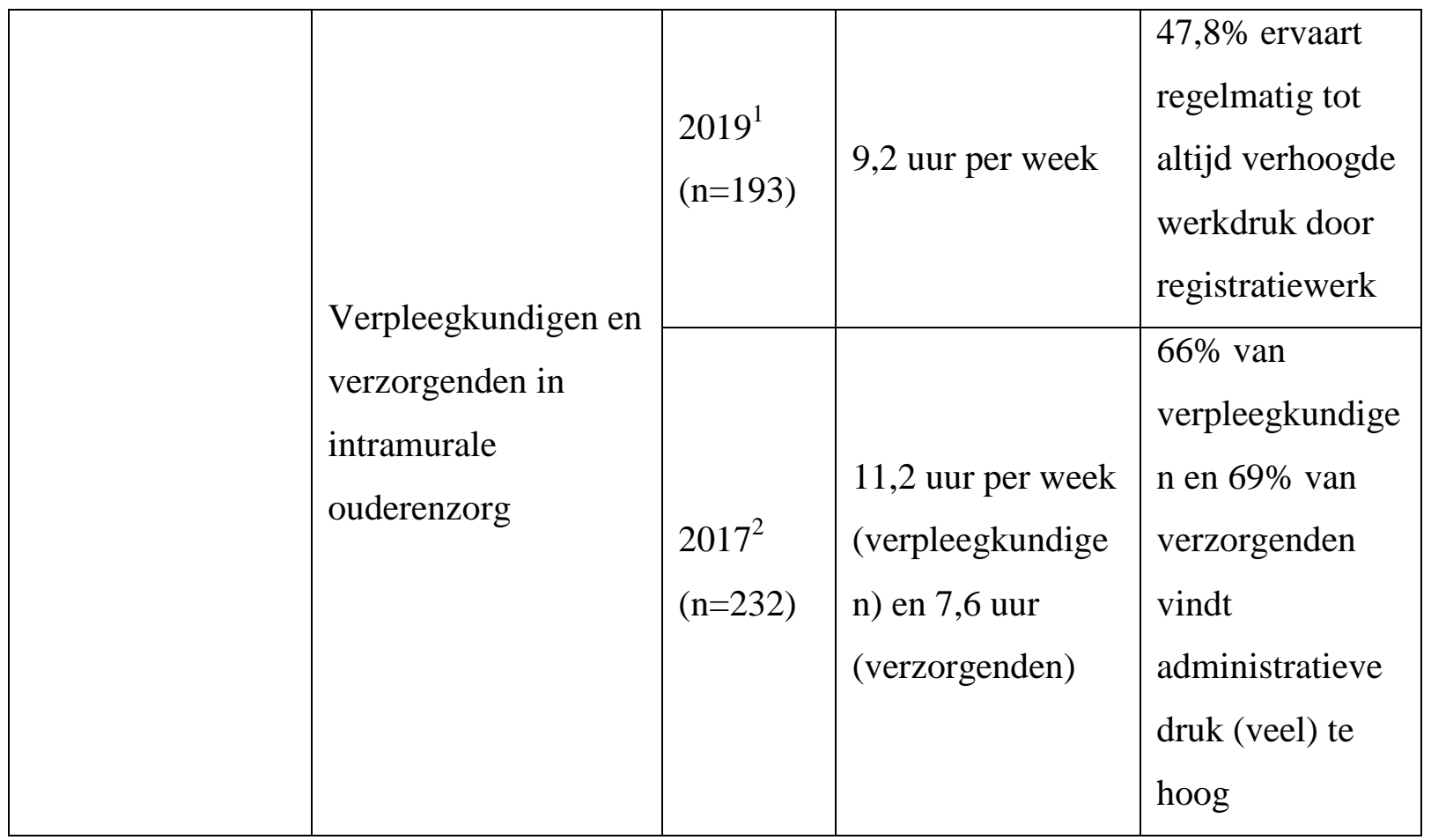

Uit deze tabel en de achterliggende onderzoeksrapporten blijkt dat de zelf gerapporteerde tijd besteed aan administratieve taken hoger is dan de zelf gerapporteerde 'acceptabele' tijd besteed aan administratieve taken. Tevens achten we een percentage van 30 à $40 \%$ relatief hoog, in het besef dat het deels gaat om taken die het werkplezier van zorgprofessionals negatief beïnvloeden.

Echter er lijken ook enkele methodologische beperkingen en tegenstrijdigheden te zijn:

- Deze onderzoeken zijn exclusief gericht op 'administratieve lastendruk', met uitzondering van het Nivel onderzoek uit 2019. Hierdoor kan selectiebias aan de orde zijn, wanneer vooral zorgprofessionals met een opinie over administratieve lasten de vragenlijst invullen.

- Voor zover ons bekend zijn de survey onderzoeken niet gevalideerd door observationeel onderzoek.

- Een goede tijdsreeks ontbreekt. De KPMG en VvAA onderzoeken zijn slechts éénmalig uitgevoerd, en de Berenschot survey is vier keer uitgevoerd maar gaat niet terug tot vòòr 2016. Aan het Nivel V\&V panel is vanaf 2011 met enige regelmaat iets gevraagd over administratie, maar pas sinds 2017 wordt de vraag gesteld hoeveel tijd eraan wordt besteed. Ook worden bevindingen per sector pas sinds 2015 gerapporteerd.

- Het valt op dat het Nivel onderzoek een daling van de administratieve lasten laat zien, terwijl het Berenschot onderzoek wijst op een stijging.

- In deze onderzoeken wordt geen onderscheid gemaakt tussen verschillende soorten administratieve werkzaamheden. Hierdoor kan geen goed onderscheid gemaakt worden tussen de tijd die professionals besteden aan bijvoorbeeld financiële administratieve, klinische documentatie, en de (acceptabele) tijd besteed aan overleggen over andere zaken dan patiëntenzorg.

We zijn benieuwd hoe u denkt over deze knelpunten. Daarom vragen we u te reageren op de volgende stellingen: 
$\rightarrow$ De bestaande survey onderzoeken naar administratieve lasten in de langdurige zorg kennen een selectiebias, doordat ze exclusief over administratieve lasten gaan.

- Eens, dit veroorzaakt een overschatting

- Eens, dit veroorzaakt een onderschatting

- Deels eens, want *tekst box*

- Oneens, want *tekst box*

- Weet niet/geen mening

$\rightarrow$ Wanneer een vraag over tijd besteed aan administratieve taken zou worden opgenomen in een regulier en breder surveyonderzoek dat langjarig uitgevoerd wordt, kan een betrouwbare reeks worden opgebouwd en vermindert de potentiële selectiebias zoals in de vorige vraag beschreven.

- Eens

- Deels eens, want *tekst box*

- Oneens, want *tekst box*

- Weet niet/geen mening

$\rightarrow$ Er zou in survey onderzoeken onder professionals moeten worden uitgevraagd uit welke componenten 'administratieve werkzaamheden' bestaan.

- Eens

- Deels eens, want *tekst box*

- Oneens, want *tekst box*

- Weet niet/geen mening

Om beter inzicht te krijgen in de componenten van 'administratieve werkzaamheden' is een rubricering nodig. In een eerdere analyse van de $\mathrm{OECD}^{3}$ is het volgende conceptuele kader hiervoor ontwikkeld op basis van observationele studies naar de tijdsbesteding van zorgprofessionals.

Conceptual overview of functions contributing to administrative workload borne by health workers

\begin{tabular}{|c|c|c|}
\hline \multirow{7}{*}{$\begin{array}{c}\text { Purely } \\
\text { administrative }\end{array}$} & \multirow[b]{2}{*}{ Financing } & Accounting and auditing \\
\hline & & $\begin{array}{l}\text { Claims, billing and } \\
\text { insurance related }\end{array}$ \\
\hline & \multirow{2}{*}{ Organisational } & Planning and scheduling \\
\hline & & HR management \\
\hline & \multirow{4}{*}{$\begin{array}{l}\text { Clinical } \\
\text { documentation }\end{array}$} & Medical records \\
\hline & & $\begin{array}{l}\text { Other data reporting } \\
\text { (e.g. quality of care) }\end{array}$ \\
\hline & & $\begin{array}{l}\text { Medication } \\
\text { administration }\end{array}$ \\
\hline $\begin{array}{c}\text { Mixed } \\
\text { administrative } \\
\text { and clinical }\end{array}$ & & $\begin{array}{l}\text { Patient correspondence, } \\
\text { discharge letters and } \\
\text { documents }\end{array}$ \\
\hline
\end{tabular}

${ }^{3}$ OECD (2017) ‘Tackling Wasteful Spending on Health'. Paris: OECD Publishing 
$\rightarrow$ Hoe beoordeelt $\mathrm{u}$ de compleetheid van deze rubricering?

*tekst box*

$\rightarrow$ Kent $\mathrm{u}$ andere indelingen die bruikbaar zijn voor de rubricering van administratieve taken uitgevoerd door zorgprofessionals?

*tekst box*

De tegenstrijdigheid tussen het Berenschot onderzoek (waarin administratieve lasten toenemen) en het Nivel onderzoek (waarin administratieve lasten afnemen) roept vragen op.

$\rightarrow$ Kent $\mathrm{u}$ recente voorbeelden of verklaringen voor de geobserveerde toe- en/of afname in administratieve lasten bij zorgprofessionals werkzaam in de langdurige zorg?

- Voorbeelden toename

*tekst box*

- Voorbeelden afname

*tekst box*

Kent $\mathrm{u}$ andere databronnen over de tijd besteed aan andere zaken dan patiëntenzorg door zorgprofessionals werkzaam in de langdurige zorg, buitend de in de tabel benoemde studies door KPMG, Berenschot, VvAA en Nivel?

*tekst box*

Heeft u nog andere opmerkingen over de tijd besteed aan andere zaken dan patiëntenzorg door zorgprofessionals werkzaam in de langdurige zorg?

*tekst box* 


\section{Vraaggroep 2 - Meso deel. Overheadkosten van langdurige zorginstellingen}

Bent $\mathrm{u}$ bekend met data over overhead op dit niveau? Het gaat hier bijvoorbeeld om de kosten van langdurige zorginstellingen gerelateerd aan niet-cliëntgebonden personeel, dat actief is op het gebied van financiën, administratie en secretariële ondersteuning. Indien niet, dan kunt u op 'nee' klikken en deze vraaggroep overslaan.

$\mathrm{Ja} / \mathrm{nee}$

Voor het meso deel hebben we twee bronnen gevonden: 1) via de jaarverslagen worden data verzameld over de verhouding tussen cliëntgebonden en niet-cliëntgebonden personeel bij zorginstellingen, en 2) Berenschot verzamelt in opdracht van langdurige zorginstellingen informatie over hun FTE en kosten die als overhead worden aangemerkt.

1) Verhouding cliëntgebonden en niet-cliëntgebonden personeel uit jaarverslagen Grote zorginstellingen moeten in hun jaarverslagen aangeven wat de verhouding is van cliëntgebonden en niet-cliëntgebonden personeel. Kleine zorginstellingen hoeven deze informatie niet aan te leveren. Zorginstellingen worden als 'kleine entiteiten' gezien als zij een netto omzet van minder dan $€ 700.000$; gemiddeld minder dan 10 werknemers hebben; en/of de waarde van het activa niet meer is dan $€ 350.000$.

Het is aan zorginstellingen zelf om te bepalen wat zij onder 'cliëntgebonden personeel' verstaan. Dit zien wij niet als een probleem, omdat we verwachten dat het onderscheid tussen FTE 'aan het bed' en FTE in ondersteunende functies in de boekhoudkundige praktijk goed te maken is.

Desondanks is de kwaliteit van deze data suboptimaal. Uit onderzoek van het CBS tussen 2014-2016 bleek namelijk dat het percentage instellingen per sector dat geen of inconsistente cijfers aanleverde (bijvoorbeeld een hoger aantal arbeidsjaren dan het aantal werknemers), kon oplopen tot $20 \%$.

Als gevolg van deze gebreken achten wij de jaarverslagen onvoldoende betrouwbaar om een longitudinaal beeld te vormen van overheadkosten in langdurige zorginstellingen.

$\rightarrow$ Bent $\mathrm{u}$ het hiermee eens?

- Ja

- Deels, want...

- Nee, want...

- Weet niet/geen mening

$\rightarrow$ Heeft $u$ andere opmerkingen over de data die via jaarverslagen wordt verzameld over de verhouding tussen cliëntgebonden en niet-cliëntgebonden personeel bij grote zorginstellingen?

*tekst box*

2) Berenschot Benchmark Care

Berenschot voert sinds 2003 onderzoek uit naar de overheadkosten in VVT, GHZ en RIBW instellingen. Berenschot verzamelt de data met een vragenlijst die door de instelling zelf of door Berenschot wordt ingevuld. Dit kost een instelling gemiddeld drie werkdagen. Met de ingevulde vragenlijst worden de volgende categorieën aangemerkt als zijnde overhead: 
FTE \& kosten:

- Management en staf algemene en administratieve functies (zoals raad van bestuur, directie, medewerkers communicatie, kwaliteitszorg en marketing en beleidsstaf) en personeel op het gebied van financiën \& administratie, automatisering en informatievoorziening, inkoop, personeel \& organisatie, opleiding en secretariële ondersteuning.

- Zorgmanagement (management en staf cliënt- en bewonergebonden functies en leidinggevend VOV-personeel dat voor meer dan $50 \%$ vrijgemaakt is voor leidinggevende taken) en stafpersoneel in de zorg.

- Management en staf civiele functies (onder andere leidinggevenden voor keuken, receptie, schoonmaak en logistiek).

- Terrein- en gebouwgebonden functies (veelal vastgoed, verhuur en technische dienst).

Kosten:

- Personele kosten

- Materiële kosten

- Inhuurkosten

- Uitbestedingskosten aan derden

- Overige kosten (zoals materiële kosten, huisvestingskosten, afschrijvings- en huurkosten

De volgende categorieën vallen buiten de Berenschot definitie van overheadkosten:

- Hotelfuncties (zoals de medewerkers linnenkamer, transport, keuken, receptie en schoonmaak).

- Zorgpersoneel (zoals verpleegkundigen, verzorgenden, (activiteiten)begeleiders, psychiaters, psychologen en paramedici).

- Leerlingen en stagiaires.

\section{Uitkomsten}

Berenschot publiceert data op geaggregeerd niveau, niet op het niveau van instellingen. Hieruit blijkt dat de overheadformatie in de GHZ afnam van 15,1\% in 2011 naar $12,4 \%$ in 2019. De afname in overheadkosten was kleiner. Deze bedroeg 17,3\% in 2011 en 16,4\% in 2019. In de VVT nam de overheadformatie af van $13,9 \%$ in 2011 naar $12,7 \%$ in 2019. De overheadkosten bleven gelijk. Deze bedroegen 16,3\% in 2011 en in 2019. In de RIBW nam de overheadformatie af van 17,2\% in 2014 naar 15,8\% in 2018. De overheadkosten namen toe, van $20,4 \%$ in 2014 tot $22,5 \%$ in 2018 .

Kent $\mathrm{u}$ recente voorbeelden of verklaringen voor de geobserveerde trends in overheads bij VVT, GHZ of RIBW instellingen?

VVT *tekst box*

GHZ *tekst box*

RIBW *tekst box*

Wij achten de validiteit van deze gegevens goed. Er is in onze ogen sprake van een helder definitiekader van overheadkosten met logisch te verklaren categorieën van overheadkosten.

Bent u het hiermee eens?

- Ja

- Deels, want... 
Nee, want...

- Weet niet/geen mening

Een aantal zaken spelen mee waar het gaat om de representativiteit van de Berenschot benchmark care. Zo is deelname vrijwillig, en zijn er kosten aan verbonden voor de instellingen. Deze bedragen zo'n vier- tot zesduizend euro per deelname. Dit kan selectiebias met zich meebrengen.

Over het bereik is het volgende bekend. Tussen 2016-2018 participeerden $43 \mathrm{GHZ}$ instellingen, 58 VVT instellingen, en 7 RIBW instellingen. In 2017 waren er 393 GHZ en 913 VVT instellingen (kleine instellingen uitgezonderd), en 24 RIBW instellingen. In aantallen deden van de middelgrote tot grote instellingen dus $11 \%$ (GHZ), $6 \%$ (VVT) en 29\% (RIBW) van de instellingen mee.

NB: in de GHZ en VVT waren respectievelijk 1500 en 16.500 kleine zorgondernemingen actief in 2017. Dit betreffen ondernemingen met minder dan 700.000 aan omzet en/of minder dan 10 werknemers en/of activawaarde van minder dan 350.000.

In omzet gemeten was het bereik groter omdat voornamelijk grotere instellingen deelnamen. De omzet van deelnemende GHZ instellingen betrof $€ 4,2$ miljard (44\% van het totaal). Die van VVT instellingen betrof $€ 5,2$ miljard (30\% van het totaal). Die van RIBW instellingen betrof $€ 0,3$ miljard. De totale omzet van RIBW instellingen is ons onbekend.

De overheadkosten per omzetcategorie verschillen als volgt. De overheadkosten van GHZ instellingen met minder dan $50 \mathrm{mln}$ omzet bedroegen $17,5 \%$; die van $\mathrm{GHZ}$ instellingen met 50-100 mln omzet bedroegen 15,1\%; en die van GHZ instellingen met 100-200 mln omzet bedroegen 16,6\%. Bij de VVT gaat het respectievelijk om 16,4\%; 16,6\% en 16,0\%.

Berenschot rapporteert geen cijfers per omzetcategorie over de RIBW.

$\rightarrow$ Acht $\mathrm{u}$ de resultaten van de Berenschot benchmark care voldoende representatief voor de hele sector?

- Ja

- Deels, want...

- Nee, want...

- Weet niet/geen mening

Kent $\mathrm{u}$ andere databronnen over de overheadkosten/-formatie van instellingen die langdurige zorg aanbieden, buiten de data die via jaarverslagen gegenereerd wordt en de Berenschot benchmark care?

*tekst box*

Heeft u nog andere opmerkingen over overheadkosten van langdurige zorginstellingen?

*tekst box* 


\section{Vraaggroep 3 - Macro deel. Beheerskosten van organisaties/instituten die langdurige zorg besturen of financieren}

$\rightarrow$ Bent $\mathrm{u}$ bekend met data over dit niveau? Het gaat bijvoorbeeld om de beheerskosten van (delen van) het ministerie van VWS, gemeenten en zorgkantoren, o.a. besteed aan de lonen van ambtenaren die in dergelijke organisaties bezig zijn met de langdurige zorg. Indien niet, dan kunt u op 'nee' klikken en deze vraaggroep overslaan.

$\mathrm{Ja} / \mathrm{nee}$

Voor de beheerskosten van organisaties die langdurige zorg besturen en/of financieren, kijken we in eerste instantie naar de CBS-cijfers over uitgaven aan zorg. Tot die cijfers behoren de uitgaven voor de, in internationaal verband vastgelegde, functie 'beleid en beheer', die de volgende componenten omvat:

- Bestuur en beheer van het gezondheidszorgstelsel. Omvat toezicht, bestuur, beleid, monitoring van beleid van het gezondheidszorgstelsel.

- Alle activiteiten die horen bij de financiering van de gezondheidszorg. Omvat besturen en administreren van de inkomsten voor de financiering van de gezondheidszorg, risico-verevening, het inkopen van zorg door zorgverzekeraars.

$\rightarrow$ Omvat deze omschrijving activiteiten die u niet beschouwt als uitgaven aan beleid en beheer op macro niveau?

- Nee

- Ja, zoals *tekst box*

$\rightarrow$ Ontbreken er in deze omschrijving activiteiten die $\mathrm{u}$ als beleid en beheer op macro niveau beschouwt?

- Nee

- Ja, zoals *tekst box*

Het CBS operationaliseert dit door de kosten van de volgende organisaties te includeren:

- Ministerie van Volksgezondheid, Welzijn en Sport (VWS; alleen de personeelskosten van het kerndepartement)

- CBS, afdeling gezondheidsstatistieken

- Inspectie Gezondheidszorg en Jeugd (IGJ)

- Zorginstituut Nederland (ZiNL)

- Nederlandse Zorgautoriteit (NZa)

- College Sanering Zorginstellingen (CSZ)

- Centraal Administratie Kantoor (CAK)

- Centrum Indicatiestelling Zorg (CIZ)

- Zorgkantoren

- Zorgverzekeraars (alleen de beheerskosten voor Zorgverzekeringswet en aanvullende verzekering)

- Gemeenten (alleen de beleid- en beheerskosten toegerekend aan Jeugd, WMO en publieke gezondheid)

De totale kosten van beleid en beheer volgens CBS definitie (exclusief de aanvullende verzekeringen) waren in 20182433 miljoen euro (waarvan zo'n 1100 miljoen de 
uitvoeringskosten van de Zvw door de verzekeraars betreft). Sinds 2011 is dit bedrag in absolute zin gestegen met 231 miljoen euro. Deze data voeren terug tot 1998.

$\rightarrow$ Ontbreken in deze lijst specifieke instellingen of type instellingen waarvan u de activiteiten als beleid en beheer beschouwt?

- Nee

- Ja, zoals *tekst box*

$C B \overline{S \text { beleid- en beheersfuncties zijn niet toegerekend aan verschillende zorgsectoren zoals de }}$ langdurige zorg

In de CBS data zijn alleen de beleid- en beheerkosten van het CIZ en de zorgkantoren, voor $100 \%$ gerelateerd aan de langdurige zorg. Alle overige organisaties voeren weliswaar taken uit gerelateerd aan andere zorgsectoren, zoals curatieve zorg, maar een specifieke toerekening ontbreekt.

Om te weten welk deel van de beleid- en beheersfuncties van deze organisaties toegerekend kan worden aan de langdurige zorg, hebben we gekeken of dit 'bottom up' te achterhalen is met openbaar beschikbare bronnen. Alhoewel organisaties zoals het ministerie van VWS, de IGJ, zorgverzekeraars, de NZa, het Zorginstituut en het CAK doorgaans zijn georganiseerd conform de inrichting van het zorgstelsel, blijken de jaarverslagen van deze organisaties geen informatie te bevatten over de kosten van de verschillende directies die bezig zijn met langdurige zorg.

Hieruit volgt dat we de beheerskosten die gerelateerd zijn aan de langdurige zorg enkel 'top down' kunnen inschatten. Het lijkt ons het meest zuiver om hiervoor het aandeel van de langdurige zorg in de totale zorguitgaven te gebruiken. We gebruiken hiervoor de volgende verdeelsleutels:

- Van de uitvoeringskosten Zvw rekenen we een deel toe aan de langdurige zorg op basis van het aandeel van wijkverpleging en geriatrische revalidatie samen in de totale Zvw-zorg (conform cijfers van het Zorginstituut); dat aandeel is ongeveer $10 \%$.

- De kosten bij gemeenten rekenen we bijna volledig (voor 95\%) toe aan de langdurige zorg; een klein deel van die beleid- en beheerskosten rekenen we toe aan het taakveld volksgezondheid, op basis van de IV3-cijfers van gemeenten.

- Van de resterende nog onverdeelde posten (VWS, IGJ, ZiNL, NZa, CSZ, CAK, en de CBS-afdeling gezondheidsstatistieken) wijzen we een gedeelte toe aan de langdurige zorg, op basis van het aandeel van de uitgaven aan de langdurige zorg in de totale zorguitgaven excl. beheerskosten. Daarvoor gebruiken we de internationale definitie van gezondheidszorg, aangevuld met het deel van de langdurige zorg dat in de internationale definitie niet meetelt (dat betreft m.n. de WMO). Kinderopvang en welzijnswerk tellen niet mee in deze afbakening. Dit leidt tot een toerekening sleutel van 35 à 37\% tussen 2010 en 2018.

- Daar komen 100\% van de beleid- en beheerskosten van zorgkantoren en het CIZ bovenop.

Dit leidt tot langdurige zorg gerelateerde administratieve kosten van 797 miljoen in 2011 en 884 miljoen in 2018. Relatief gezien komt dat neer op 3,0\% van de totale langdurige zorguitgaven in 2011 en 2,8\% in 2018.

Tussen 2011 en 2018 zijn er geen noemenswaardige definitiewijzigingen in de CBS statistieken geweest. 


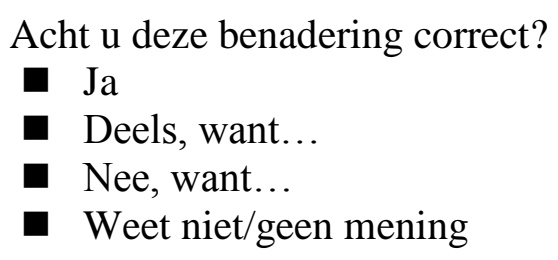

De hiervoor beschreven benadering heeft als nadeel dat we er niet de specifieke gevolgen van de hervorming langdurige zorg in 2015 op de beheerskosten in terug kunnen zien. De beheerskosten voor de langdurige zorg worden immers met een generieke sleutel berekend, die enkel rekening houdt met het aandeel van de langdurige zorg in de totale zorguitgaven.

De uitgaven van organisaties die enkel met langdurige zorg bezig zijn kunnen wel gebruikt worden om te kijken of de hervorming in 2015 een effect had. Onderstaande tabel geeft de beheerskosten in de AWBZ/WLZ (zorgkantoren en CIZ) weer. De sterke stijging in 2017 blijkt bij nader inzien geen reële stijging, maar het gevolg van het feit dat de beheerskosten van het SVB (voor hun PGB-taken) pas met ingang van 2017 ten laste van de WLZ kwamen, en van het feit dat de kosten van de taken die het CAK per 1-1-2017 van het ZiNL heeft overgenomen (onverzekerden, wanbetalers) per abuis meegeteld zijn als WLZ-lasten (dit zal bij de eerstvolgende revisie van de CBS-cijfers gecorrigeerd worden). Deze twee factoren veroorzaken vrijwel de gehele stijging van de beleid- en beheerskosten in 2017. Als hiervoor gecorrigeerd wordt, dan zijn de beleid- en beheerskosten als percentage van de totale AWBZ/WLZ-uitgaven ná de hervorming in 2015 iets hoger dan daarvoor (grofweg 1,4\% versus $1,1 \%)$.

\begin{tabular}{|l|c|c|c|c|c|c|}
\hline & 2013 & 2014 & 2015 & 2016 & 2017 & 2018 \\
\hline $\begin{array}{l}\text { Totaal uitgaven zorg en welzijn in } \\
\text { AWBZ/WLZ, in mln euro }\end{array}$ & $\begin{array}{c}24,9 \\
68\end{array}$ & $\begin{array}{c}25,1 \\
94\end{array}$ & $\begin{array}{c}17,8 \\
87\end{array}$ & $\begin{array}{c}18,1 \\
46\end{array}$ & $\begin{array}{c}18,7 \\
35\end{array}$ & $\begin{array}{c}19,6 \\
36\end{array}$ \\
\hline $\begin{array}{l}\text { Uitgaven aan beleid en beheer in AWBZ/WLZ, } \\
\text { in mln euro }\end{array}$ & 284 & 289 & 262 & 257 & 313 & 327 \\
\hline $\begin{array}{l}\text { Aandeel beleid en beheer in totale AWBZ/Wlz } \\
\text { uitgaven }\end{array}$ & $1,1 \%$ & $1,1 \%$ & $1,5 \%$ & $1,4 \%$ & $1,7 \%$ & $1,7 \%$ \\
\hline $\begin{array}{l}\text { Jaarlijkse groei AWBZ/Wlz beleid en beheer } \\
\text { uitgaven }\end{array}$ & $23 \%$ & $2 \%$ & $-9 \%$ & $-2 \%$ & $22 \%$ & $4 \%$ \\
\hline
\end{tabular}

Bron: https://opendata.cbs.nl/statline/\#/CBS/nl/dataset/84043NED/table?dl=219BD.

$\rightarrow$ Heeft $\mathrm{u}$ een verklaring voor de groei van 0,3 à 0,4 procentpunt in het aandeel van de beleid- en beheerskosten van de totale AWBZ/WLZ uitgaven voor en na de hervorming in 2015 ?

*tekst box*

$\rightarrow$ Kent $\mathrm{u}$ andere recente voorbeelden of verklaringen van toe- en/of afname van beleid- en beheerskosten in de langdurige zorg volgens CBS definitie?

- Voorbeelden toename

*tekst box*

- Voorbeelden afname

*tekst box* 


\section{Opties om de WMO beheerskosten van gemeenten in te schatten}

$\rightarrow$ Bent $\mathrm{u}$ bekend met data over gemeentelijke uitgaven? Indien niet, dan kunt u op 'nee' klikken en deze vraaggroep overslaan.

$\mathrm{Ja} / \mathrm{nee}$

Het CBS gebruikt voor de beleid- en beheerskosten van gemeenten een schatting. Aangezien de hervorming langdurige zorg in 2015 voor gemeenten een majeure wijziging betrof, is dat problematisch om in te kunnen schatten welk effect deze hervorming had op de administratieve kosten in de langdurige zorg. Opmerkelijk genoeg vinden we op basis van de salarisbestanden van gemeenten dat er sinds 2010 sprake lijkt van een daling in de totale personele bezetting bij gemeenten:

Ontwikkeling van de gemeentelijke bezetting, in FTE

\begin{tabular}{|r|r|r|r|r|r|r|r|r|}
\hline 2010 & 2011 & 2012 & 2013 & 2014 & 2015 & 2016 & 2017 & 2018 \\
\hline 154.670 & 151.478 & 147920 & 143300 & 138670 & 137080 & 137930 & 140980 & 139910 \\
\hline
\end{tabular}

Deze FTE zijn echter niet specifiek toe te wijzen aan WMO taken. Dit is ook het geval voor de uitgavenpost 'overhead' in de CBS statistieken over gemeentelijke uitgaven.

Gemeenten registreren de gemeentelijke baten en lasten met de IV3-systematiek. Deze is zowel in 2015 als in 2017 gewijzigd. Met ingang van 2017 is er een aparte post 'overhead' geïntroduceerd. Dit betreft de algemene overhead, die niet aan specifieke taakvelden toegerekend kan worden. Deze post bedroeg in 2018 6,5 miljard, 9,9\% van de totale gemeentelijke lasten.

De lasten van de taakvelden langdurige zorg (maatwerkdienstverlening 18+, geëscaleerde zorg 18+, maatwerkvoorziening WMO en algemene voorzieningen incl. wijkteams) bedroegen in 2018 bijna 9 miljard euro, dat is $15 \%$ van de totale gemeentelijke lasten minus overhead. Als we de 'overhead' posten naar rato aan de taakvelden toewijzen, dan komt dat voor de langdurige zorg neer op 977 miljoen (15\% van 6,5 miljard). Hierbij dient opgemerkt dat de post algemene voorzieningen en wijkteams betrekking heeft op het gehele sociale domein. Deze omvat dus meer dan alleen langdurige zorg.

Afgezien van de precieze afbakening van 'langdurige zorg', acht u dit een plausibele manier om een deel van de algemene overheadkosten van gemeenten toe te wijzen aan het WMO-terrein?

- Ja

- Deels, want...

- Nee, want...

- Weet niet/geen mening

In de huidige IV3-systematiek maakt de taakveld-specifieke overhead deel uit van de lasten die op dat taakveld gerapporteerd worden. Om het overhead-deel van deze lasten te schatten, zou men de lonen/salarissen, de kosten van ingehuurd personeel en de ingekochte goederen en diensten kunnen zien als overhead. Dit is echter een grove aanname waarbij de gedachte is dat al het personeel in dienst bij de gemeente zelf geen zorg verleent en dus gezien kan worden als overhead (wat in het geval van wijkteams zeker niet bij alle gemeenten zal kloppen). Deze gegevens per kostensoort zijn voor veel maar niet alle gemeenten alleen in de 
vorm van onbewerkte open data beschikbaar (https://iv3statline.cbs.nl/\#/IV3/nl/dataset/45042NED/table?dl=38188).

$\rightarrow$ Bij welke van de volgende taakvelden acht $u$ het acceptabel om de som van de genoemde kostenposten als een schatting van de taakveld-specifieke overhead te zien?

\begin{tabular}{|l|l|l|}
\hline $\begin{array}{l}\text { Samenkracht en } \\
\text { burgerparticipatie }\end{array}$ & Wel & Niet \\
\hline Wijkteams & Wel & Niet \\
\hline Maatwerkvoorziening (WMO) & Wel & Niet \\
\hline Maatwerkdienstverlen 18+ & Wel & Niet \\
\hline Maatwerkdienstverlen 18- & Wel & Niet \\
\hline Geëscaleerde zorg 18+ & Wel & Niet \\
\hline Geëscaleerde zorg 18- & Wel & Niet \\
\hline
\end{tabular}

$\rightarrow$ Acht $\mathrm{u}$ de onbewerkte open data van gemeenten geschikt voor dit doel?

- Ja

- Deels, want...

- Nee, want...

- Weet niet/geen mening

Kent u naast de gegevens die via IV3 systematiek geregistreerd worden, andere bronnen die inzicht bieden in de beleid- en beheerskosten van gemeenten, gerelateerd aan de langdurige zorg en het sociaal domein?

*tekst box*

\section{Mogelijke additionele beleid- en beheerskosten}

In de (wereldwijd door statistiekbureaus gehanteerde) Standaard BedrijfsIndeling (SBI) voor de gezondheid- en welzijnszorg zitten categorieën bedrijven die activiteiten uitvoeren die mogelijk ook als beleid en beheer/overhead gezien kunnen worden, maar geen onderdeel uitmaken van de manier waarop het CBS de functie 'beleid en beheer' operationaliseert.

De eerste van deze twee categorieën is: Andere zorgondersteunende diensten (86929) in de gezondheidszorg. Hiertoe behoren o.a. de onderstaande activiteiten.

$\rightarrow$ Welke van deze activiteiten zou u rekenen tot beleid en beheer/overhead?

1. Voorlichting over, advisering over, coördinatie en begeleiding van activiteiten op het gebied van gezondheidszorg zonder zelf patiëntenzorg uit te voeren; wel/niet

2. Overkoepelende organen voor instellingen in de gezondheidszorg (niet zijnde werkgeversorganisaties in de gezondheidszorg of- verenigingen van vrije beroepsbeoefenaren in de gezondheidszorg); wel/niet

3. Wachtlijstbemiddeling voor patiënten; wel/niet 
4. Niet elders genoemde activiteiten op het gebied van gezondheidszorg zonder zelf patiëntenzorg uit te voeren, zoals het organiseren van reanimatiecursussen, EHBOcursussen, zwangerschapscursussen e.d., plaatselijke Rode kruisverenigingen. $\mathrm{wel} / \mathrm{niet}$

Toelichting *tekst box*

De tweede categorie behoort tot het domein van de langdurige en welzijnszorg: Overig maatschappelijk advies, gemeenschapshuizen en samenwerkingsorganen op het gebied van welzijn (88999). Hiertoe behoren o.a. de onderstaande activiteiten.

$\rightarrow$ Welke van deze activiteiten zou u rekenen tot beleid en beheer/overhead?

1. Overkoepelende organen, samenwerkings- en adviesorganen en fondsen op het gebied van welzijnswerk; wel/niet

2. Voorlichting en advisering over, coördinatie en begeleiding van activiteiten op het gebied van welzijnswerk zonder zelf welzijnswerk uit te voeren. Wel/niet

3. Fondsen ten behoeve van individuen en instellingen op het gebied van welzijn; bemiddeling schuldsanering, budget coaching, bemiddeling thuiszorg, beheer van Persoonsgebonden Budget (PGB); wel/niet

4. Bemiddelen en belangenbehartiging van vrijwilligers in de welzijnszorg; wel/niet

Toelichting *tekst box*

De begroting van het ministerie van VWS is een andere vindplaats voor 'restpost' categorieën die niet als beleid- en beheerskosten zijn aangemerkt, maar dat mogelijk wel zijn. Dergelijke categorieën van substantiële grootte zijn met name aan de orde bij de financieringsinstrumenten 'bijdragen aan agentschappen en zelfstandige bestuursorganen' en 'subsidies'. Het CBS includeert reeds de personeelskosten van het VWS kerndepartement, en de meeste bijdragen aan agentschappen en zelfstandige bestuursorganen zoals de IGJ, het Zorginstituut en de NZa.

Het CBS includeert echter niet de subsidies van VWS als beleid- en beheerskosten, maar als zorguitgaven indien deze terecht komen bij zorgaanbieders. De uitgaven aan subsidies betroffen in 2018 in totaal $€ 1346 \mathrm{mln}$. Een flink deel daarvan betreft in geen geval beleid- en beheerskosten, zoals regelingen voor publieke en seksuele gezondheid, de uitvoering van de Niet Invasieve Prenatale Test (NIPT) of de bekostiging van schippersinternaten. Voor andere subsidies is het minder evident om te bepalen of ze als overhead of als zorg gezien moeten worden.

$\rightarrow$ Daarom vragen we u welke van de volgende subsidieregelingen binnen de VWSbegrotingsartikelen 'langdurige zorg en ondersteuning' en 'zorgbreed beleid' u zou rekenen tot beleid- en beheerskosten/overhead:

1. Nationaal programma palliatieve zorg (€30 $\mathrm{mln}$ in 2018).

wel/niet 
2. Programma 'thuis in het verpleeghuis: waardigheid en trots op elke locatie' (€18 mln in 2018).

wel/niet

3. Programma 'gehandicaptenzorg: volwaardig leven' (€5 $\mathrm{mln}$ in 2018).

wel/niet

4. Arbeidsmarktagenda verpleeghuiszorg ( $€ 65 \mathrm{mln}$ in 2018).

wel/niet

5. Programma 'innovatie en zorgvernieuwing' (€8 $\mathrm{mln}$ in 2018).

wel/niet

Toelichting *tekst box*

\section{Brancheorganisaties en kennisinstellingen vallen buiten de CBS data}

Het CBS neemt brancheorganisaties en kennisinstellingen niet mee in de beleid- en beheerskosten van de zorg, primair omdat deze organisaties in de Standaard Bedrijfs indeling niet gezien worden als zorgaanbieders. Opname van dit soort organisaties die zich bezighouden met de zorg in de Zorgrekeningen, zou tot overlap leiden met de statistieken over onderzoek, onderwijs, openbaar bestuur, etcetera. Ook is overlap mogelijk met zorgaanbieders omdat kennisinstellingen en brancheorganisaties deels gefinancierd worden door zorgaanbieders.

Brancheorganisaties van financiers en aanbieders van langdurige zorg zijn o.a. de Vereniging Nederlandse Gemeenten (VNG), Zorgverzekeraars Nederland en Actiz. Kennisinstellingen die langdurige zorg onderzoeken, monitoren, of advies geven, zijn o.a. Vilans, het Sociaal Cultureel Planbureau (SCP) en ZonMw.

$\rightarrow$ Afgezien van mogelijke dubbeltellingen, zouden brancheorganisaties zoals de VNG en Actiz volgens $u$ onderdeel uit moeten maken van de administratieve kosten van de langdurige zorg op macro niveau?

- Ja, want *tekst box*

- Nee, want $*$ tekst box*

- Weet niet/geen mening

Afgezien van mogelijke dubbeltellingen, zouden kennisinstellingen volgens $u$ onderdeel uit moeten maken van de administratieve kosten van de langdurige zorg op macro niveau?

- Ja, want *tekst box*

- Nee, want *tekst box*

- Weet niet/geen mening

\section{Uitgaventrends door brancheorganisaties}

Afgezien van mogelijke dubbeltellingen, kunnen de uitgaventrends van enkele belangrijke brancheorganisaties wel een indicatie geven over de impact van de hervorming langdurige zorg. Ons viel de uitgavengroei van de VNG op:

Uitgaven Vereniging Nederlandse Gemeenten (incl. VNG Realisatie-voorheen KING), in mln euro's

\begin{tabular}{|l|l|l|l|l|l|l|l|l|l|}
\hline & 2010 & 2011 & 2012 & 2013 & 2014 & 2015 & 2016 & 2017 & 2018 \\
\hline
\end{tabular}




\begin{tabular}{|l|l|l|l|l|l|l|l|l|l|}
\hline VNG & 42,6 & 41,7 & 49,6 & 50,7 & 68,86 & 111,5 & 113,2 & 127,1 & 104,8 \\
\hline
\end{tabular}

De kostenontwikkeling van de VNG toont een duidelijke trendbreuk in 2015, het jaar van de hervorming langdurige zorg. Deze trendbreuk lijkt een gevolg van de decentralisaties in dat jaar, omdat de activiteitskosten (voorlichting, bijeenkomsten, onderzoek, etc) van de VNG met ruim 41 miljoen toenamen van 2014 op 2015.

$\rightarrow$ Kent $\mathrm{u}$ recente voorbeelden of verklaringen van toe- en/of afname van beleid- en beheerskosten bij brancheorganisaties in de langdurige zorg, zoals de VNG?

Voorbeelden toename

*tekst box*

Voorbeelden afname

*tekst box*

\section{Uitgaventrends door kennisinstellingen}

Onder anderen Vilans, SCP, de RVS, de Gezondheidsraad, Nivel, Movisie, RIVM, ZonMw en universiteiten doen onderzoek naar, monitoren, of geven advies over o.a. de langdurige zorg. In verband met dubbeltellingen met o.a. de VWS begroting, uitgaven van zorgaanbieders, en statistieken over onderzoek, onderwijs, openbaar bestuur, kunnen we de kosten van deze organisaties niet optellen bij de beleid- en beheerskosten volgens CBS definitie.

Wel kunnen we naar de langdurige zorg-gerelateerde uitgaven van deze organisaties kijken, om een beeld te vormen of de hervorming in 2015 leidde tot meer of minder beleid- en beheerskosten in de vorm van onderzoek, monitoring, advisering, etc.

- Vilans doet uitsluitend onderzoek naar langdurige zorg. De uitgaven van Vilans zijn tussen 2010 en 2018 met $68 \%$ gestegen:

Uitgaven Vilans, in mln euro's. Bron: jaarverslagen Vilans.

\begin{tabular}{|r|r|r|r|r|r|r|r|r|}
\hline 2010 & 2011 & 2012 & 2013 & 2014 & 2015 & 2016 & 2017 & 2018 \\
\hline 22,6 & 28,7 & 34,4 & 32,1 & 30,6 & 32,9 & 34,5 & 38,1 & 38,0 \\
\hline
\end{tabular}

- De totale kosten van het SCP, de RVS, de Gezondheidsraad ${ }^{4}$, Nivel en Movisie bedroegen in 2018 50,6 mln. In 2010 was dit 54,4 mln. Deze bedragen betreffen de totale uitgaven. Wanneer we een grove verdeelsleutel ${ }^{5}$ toepassen, dan komen we uit op 13,5 mln in 2018 en 15,6 mln in 2010 wat gerelateerd kan zijn aan de langdurige zorg.

- We tellen het RIVM niet mee omdat RIVM relatief weinig onderzoek doet naar langdurige zorg terwijl de totale RIVM kosten hoog zijn.

- Om de langdurige zorg-gerelateerde kosten van ZonMw in te schatten hebben we de jaarverslagen van ZonMw gebruikt. We hebben de programma's geïncludeerd waar in minstens 1 jaar meer dan 1 mln omging, en waarbij uit de titel van het programma

\footnotetext{
${ }^{4}$ De kosten van het SCP, de RVS en de Gezondheidsraad zijn achterhaald via de begroting van VWS, waar ze onder één uitgavenpost vallen. Hieronder vallen ook de Sportraad en voorheen de RMO.

${ }^{5}$ SCP en raden voor $3 / 16^{\mathrm{e}}$ op basis van het organogram van het SCP; Nivel voor $35 \%$ aangezien het werk van Nivel redelijk gelijkmatig het hele zorgveld beslaat waardoor we het aandeel van de langdurige zorg in de totale zorguitgaven kunnen gebruiken, en Movisie voor $1 / 3^{\mathrm{e}}$ op basis van het organogram van Movisie.
} 
blijkt dat het ging om de langdurige zorg (VVT, GHZ, RIBW). Conform de huidige indeling van de ZonMw programma's komt dat neer op de meeste programma's die momenteel vallen onder de programma's 'gehandicapten en chronisch zieken', 'ouderen', 'palliatieve zorg', en het 'actieprogramma mensen met verward gedrag'. Daarnaast hebben we programma's waarbij fundamenteel onderzoek leidend was, of waarbij de focus op Zvw zorg lag, uitgesloten. Hierdoor vielen 'Memorabel', 'priority medicines ouderen', en 'huisartsgeneeskunde en ouderengeneeskunde' af. Aan de programmakosten van overblijvende programma's hebben we een aandeel van de ZonMw exploitatiekosten toegevoegd, op basis van het aandeel van betreffende programma's in de totale ZonMw programmakosten. Dit leverde de volgende reeks op:

ZonMw uitgaven gerelateerd aan langdurige zorg (programmakosten + exploitatiekosten), in mln euro's. Bron: jaarverslagen ZonMw.

\begin{tabular}{|r|r|r|r|r|r|r|r|r|r|}
\hline 2010 & 2011 & 2012 & 2013 & 2014 & 2015 & 2016 & 2017 & 2018 & 2019 \\
\hline 36,1 & 31,1 & 22,2 & 13,5 & 13,9 & 13,8 & 14,6 & 24,5 & 30,9 & 91,1 \\
\hline
\end{tabular}

Samenvattend zien we een stijging van de kosten van Vilans van 22,6 mln in 2010 naar 38 mln in 2018. De kosten van het SCP, adviesraden, Nivel en Movisie bedragen toegerekend naar de langdurige zorg een beperkt bedrag van 13 à 16 mln euro tussen 2010 en 2018, waarbij in 2019 fors meer werd uitgegeven dan in voorgaande jaren. Als laatste zien we een fluctuerend beeld in de uitgaven van ZonMw die gerelateerd zijn aan langdurige zorg. Deze laatste uitgaven kunnen niet opgeteld worden bij de uitgaven van Vilans, Nivel en Movisie, omdat deze organisaties ook ontvanger zijn van ZonMw subsidies.

Acht $\mathrm{u}$ deze benadering correct?

- Ja

- Deels, want...

- Nee, want...

- Weet niet/geen mening

$\rightarrow$ Kent $\mathrm{u}$ recente voorbeelden of verklaringen van toe- en/of afname van beleid- en beheerskosten bij kennisinstellingen die onderzoek doen naar de langdurige zorg?

Voorbeelden toename

*tekst box*

Voorbeelden afname

*tekst box* 
Wij danken $u$ hartelijk voor het invullen van deze vragenlijst. Graag bespreken we de bevindingen van uw antwoorden en die van andere participanten in een (online) expertsessie die ongeveer 1,5 uur in beslag zal nemen. Deze sessie zal in juli plaatsvinden.

$\rightarrow$ Bent u bereid om deel te nemen aan deze sessie?

- Ja

- Nee 